\title{
MICROBIAL HAZARDS ASSESSMENT DURING WHITE CHEESE PRODUCTION IN A TRADITIONAL DAIRY PLANT
}

\author{
AHMED S. AIAD
}

Animal Health Research Institute, Alexandria

\section{ABSTRACT}

Received at: $10 / 3 / 2013$

Accepted: 30/3/2013
This study has been conducted to determine the microbiological contamination sources during production of white soft cheese in a local dairy plant, in Alexandria city, Egypt. A total of 180 representative samples ( coming raw milk, cheese vat, cheese mould, wooden tables, cheese handler, water supply, wall, plastic package and white soft cheese) 20 of each. The trials repeated 3 times to ensure the most contaminated points. The highest total mesophilic bacterial count was found in Cheese mould with $9.4 \times 10^{6} \pm 3.7 \times 10^{4} \mathrm{cfu} / \mathrm{cm}^{2}$ followed by Plastic package with $2.1 \times 10^{6} \pm 3.6 \times 10^{4} \mathrm{cfu} / \mathrm{cm}^{2}$. The most contaminated point with coliforms was cheese vat with a mean count of $6.1 \times 10^{4} \pm 1.11 \times 10^{3}$ followed by cheese handler with a mean count of $5.6 \times 10^{3} \pm 1.8 \times 10^{2}$. The most contaminated point with a total psychrotrophic count was cheese vat with a mean count of $4.5 \times 10^{5} \pm 6.4 \times 10^{4}$ followed by water supply with a mean count of $3.7 \times 10^{5} \pm 1.9 \times 10^{4}$. The highest $S$ aureus count was found in cheese handler by $9.4 \times 10^{4} \pm 5.6 \times 10^{3}$ followed by the wall with a mean count of $8.5 \times 10^{3} \pm$ $2.3 \times 10^{3}$. Enterococci count contaminated wooden table with a mean value of $2.8 \times 10^{4} \pm$ $1.3 \times 10^{2}$ followed by water supply with a mean count of $1.3 \times 10^{3} \pm 4.7 \times 10^{2}$. The most contaminated point with yeast and mould was cheese mould with a mean count of $5.8 \times 10^{3} \pm$ $1.3 \times 10^{2}$ followed by wooden table with a mean count of $3.4 \times 10^{3} \pm 1.6 \times 10^{2}$. The most contaminated points which affect the microbial quality of white soft cheese during processing were cheese mould followed by wooden table, cheese handler and cheese vat. The application of the hygienic measures for manufacturing of the dairy products greatly improves their quality. The hygienic measures include cooling of the milk, heat treatment, use of clean water, personal hygiene of cheese handler, sterilization of equipment and prevent of post contamination during manufacture. A HACCP - based risk assessment and good manufacturing practice should be employed for all stages of manufacture of soft cheese.

Key words: HACCP, White cheese, Dairy plant

\section{INTRODUCTION}

The main potential hazards in most dairy products are microbiological hazards and the dairy industry has increased its efforts for quality and safety assurance through the development and implementation of protective programs as HACCP and quality assurance system. (Kassem et al., 2002). White soft cheese is one of the common delicious cheeses consumed in Egypt. Their manufacture and handling techniques in Egyptian markets are still primitive and unhygienic, Many contaminants find their way to raw milk, from which they gain access to dairy products (Sadek et al., 2009).

The successful commercial production of dairy products requires control of microbiological presence and activity to achieve maximum shell-life consistent with safety of the product (pelecszynska and Libelt, 1995).

The microbial quality and safety of Egyptian white soft cheese, is the major area of concern for producers, public health authorities and consumers. It depends on the types of microorganisms introduced from raw milk, efficiency of processing and the hygienic practice applied in small or big dairy plant or informal producers. Handling of milks during cheese manufacture play an important role in the proliferation of microbial flora and consequently impair its utility and render the product unfit for human consumption (Aly and Galal., 2002). The microbial quality of used raw milk in soft cheese has an important role in the quality of yielded cheese. Many researchers have recorded unlimited microbial flora in the raw milk (Hayes et al., 2001).

Food borne diseases are a common and widespread global problem. Several outbreaks have been reported as a result of eating contaminated dairy food that may look, taste and smell perfectly normal but are in fact contaminated with large number of harmful bacteria (CDC, 2009).

Egyptian standard (2005) stated that soft cheese must be free from any pathogenic microorganisms, while 
coliform counts must be less than $10 \mathrm{cfu} / \mathrm{g}$, total yeast counts less than $400 \mathrm{cfu} / \mathrm{g}$ and total mold counts less than $10 \mathrm{cfu} / \mathrm{g}$.

Microorganisms may gain access to cheese during process, handling and distribution since milk provide a high nutritive, favorable media for the growth and multiplication of such organisms. Many food poisoning outbreaks may be due to using milk from diseased animals with infection of bacterial origin or manufacturing in contaminated places or from the workers themselves. Ingestion of certain microorganism can be detrimental to human health (UNEP, 1992). Coliforms are routinely used as indicator to a certain the quality of the food products. Their presence indicates careless methods of production, handling of the processed food products and the use of in sufficient sanitized equipment. Moreover, Coliforms are used to measure the quality of the practices used to minimize microbial contamination of dairy products and as an approved safety indicator in HACCP system (Banwart, 1998).

The presence of staphylococcus aureus in dairy products is a good indicator of the personal hygiene of factory workers, high coliform in these products induce undesirable changes that lower their quality, presence of moulds and yeasts in dairy products is undesirable even when found in few numbers as they rapidly grow in the product that render it of inferior quality (Hamed, 1992).

Handling of milk during cheese manufacture plays an important role in the proliferation of microbial flora and consequently impairs its utility and renders the product unfit for human consumption (Yousef et al., 2001). Mould and yeast counts in cheese are used as an index of the proper sanitation and quality defects in soft cheese as rancidity, softness and colour defects arise mainly from contamination by yeast and mould. Moreover, in view of the potential ability of some mould to produce mycotoxins during their growth thus, their presence posse potential hazards to food safety and human illness (Besancon et al., 1992).

Hazards of the dairy products mainly microbiological hazard and can provide a toll for evaluating the acceptability of the products or process designed to control presence or growth of microorganisms (Silliker, 1987).

Microbiological investigations for the different varieties of Egyptian white soft cheese have been carried out either to evaluate their qualities, hinder or minimize microbial spoilage and to determine the cheese safety as free from food borne microorganisms, (Abou-Dawood et al., 2005).

The aim of this work to assess the potential microbial Hazards in traditional dairy plant in Alexandria city through the evaluation of its microbial criteria and giving suitable recommendations to improve the hygienic quality of the dairy plant to prevent contamination and produce safe and high quality products.

\section{MATERIALS and METHODS}

The present study was carried out in a traditional dairy plant in Alexandria city. 1-Process flow diagram of soft cheese:-

Incoming raw milk $\rightarrow$ cheese vat $\rightarrow$ addition of salt $(8.5-9.5 \%) \rightarrow$ pouring of milk $\rightarrow$ heating to $38 \mathrm{c}^{\circ}$ $\rightarrow$ Renneting vats $\rightarrow$ Addition of rennet $\rightarrow$ wooden moulds $\rightarrow$ wooden cheese table $\rightarrow$ pressing $\rightarrow$ Blocking $\rightarrow$ Wrapping in polyethylene paper bags $\rightarrow$ End product (soft cheese)

\section{2- Collection of samples:-}

2-1- Collection and preparation of samples: 180 samples were taken from different sites of dairy processing lines from reception to packaging. Representative as (incoming milk- cheese vat- cheese mould- wooden table- - cheese handler-water supplywall- plastic package- soft cheese) 20 of each. The trials repeated 3 times to ensure the most contaminated point.

2-2- Incoming milk: the samples was collected in sterile sampling bottles after through mixing of the bulk(about $500 \mathrm{ml}$ each), milk in cheese vat about 500 $\mathrm{ml}$ of milk were collected after pouring into cheese vat in a sterile screw capped bottle.

2-3-Soft cheese samples: the samples was collected in sterile sampling bottles (250gm) each sample thoroughly mashed in a sterile mortar for microbiological examination. The samples were collected under hygienic condition and dispatched directly to the laboratory with a minimum of delay in an ice- box (at $4 \pm 1 \mathrm{c}^{\circ}$ ).

2-4-Other samples: samples from (cheese vat, wooden cheese table, cheese moulds and workers' hands) were collected by swab contact method (Pritchard et al., 1994). Samples from plastic packages were collected by Rinse solution method and water supply samples (A.P.H.A., 1992).

\section{3- Microbiological examination:-}

3-1-Total mesophillic bacterial count (ISO4833/2003).

3-2- Coliforms count (ISO 1991).

3-3- Total psychrotrophic count (APHA, 1992).

3-4- Staphylococcus aureus count (FDA, 2002).

3-5- Total Yasts and Moulds count (Bailey and Scott, 1998).

3-6-Total Enteroococci count (Efthymiou et al., 1974). 


\section{RESULTS}

Table 1: Statistical analytical results of Total mesophilic bacterial count and Coliforms count during processing steps of white soft cheese in traditional dairy plant.

\begin{tabular}{ccc}
\hline Item & $\begin{array}{c}\text { total mesophilic } \\
\text { bacterial count }\end{array}$ & coliforms count \\
\hline Incoming raw milk & $3.2 \times 10^{5} \pm 1.3 \times 10^{4}$ & $4.2 \times 10^{3} \pm 7.2 \times 10^{2}$ \\
\hline Cheese vat & $4.6 \times 10^{5} \pm 1.9 \times 10^{4}$ & $6.1 \times 10^{4} \pm 1.11 \times 10^{3}$ \\
\hline Cheese mould & $9.4 \times 10^{6} \pm 3.7 \times 10^{4}$ & $2.1 \times 10^{2} \pm 0.28 \times 10$ \\
\hline Wooden table & $8.5 \times 10^{5} \pm 4.6 \times 10^{3}$ & $6.2 \times 10^{2} \pm 3.5 \times 10$ \\
\hline Cheese handler & $7.5 \times 10^{5} \pm 6 \times 10^{4}$ & $5.6 \times 10^{3} \pm 1.8 \times 10^{2}$ \\
\hline Water supply & $9.4 \times 10^{5} \pm 1.7 \times 10^{3}$ & $3.9 \times 10^{2} \pm 1.6 \times 10^{2}$ \\
\hline Wall & $5.8 \times 10^{5} \pm 4.8 \times 10^{4}$ & $5.7 \times 10^{2} \pm 4.3 \times 10^{2}$ \\
\hline Plastic package & $2.1 \times 10^{6} \pm 3.6 \times 10^{4}$ & $3.8 \times 10^{2} \pm 1.4 \times 10^{2}$ \\
\hline Soft cheese & $3.9 \times 10^{7} \pm 2.8 \times 10^{5}$ & $2.4 \times 10^{2} \pm 1.3 \times 10$ \\
\hline
\end{tabular}

The highest total bacterial mesophilic count was found in cheese mould followed by plastic package. The most contaminated point with coliforms was in cheese vat followed by cheese handler.

Table 2: Total psychrotrophic count and S. aureus count during processing steps of white soft cheese in traditional dairy plant.

\begin{tabular}{ccc}
\hline Item & total psychrotrophic count & S. aureus count \\
\hline Incoming raw milk & $3.2 \times 10^{4} \pm 1.7 \times 10^{3}$ & $5.6 \times 10^{3} \pm 6.9 \times 10^{2}$ \\
\hline Cheese vat & $4.5 \times 10^{5} \pm 6.4 \times 10^{4}$ & $2.5 \times 10^{3} \pm 1.5 \times 10^{3}$ \\
\hline Cheese mould & $7.4 \times 10^{4} \pm 2.7 \times 10^{4}$ & $2.4 \times 10^{3} \pm 1.7 \times 10^{3}$ \\
\hline Wooden table & $6.8 \times 10^{4} \pm 2.3 \times 10^{4}$ & $1.8 \times 10^{3} \pm 3.7 \times 10^{3}$ \\
\hline Cheese handler & $5.8 \times 10^{4} \pm 3.6 \times 10^{4}$ & $9.4 \times 10^{4} \pm 5.6 \times 10^{3}$ \\
\hline Water supply & $3.7 \times 10^{5} \pm 1.9 \times 10^{4}$ & $6.5 \times 10^{2} \pm 1.7 \times 10^{2}$ \\
\hline Wall & $8.7 \times 10^{4} \pm 3.4 \times 10^{4}$ & $8.5 \times 10^{3} \pm 2.3 \times 10^{3}$ \\
\hline Plastic package & $6.8 \times 10^{4} \pm 8.5 \times 10^{3}$ & $3.6 \times 10^{3} \pm 1.6 \times 10^{3}$ \\
\hline Soft cheese & $5.9 \times 10^{7} \pm 6.3 \times 10^{6}$ & $7.8 \times 10^{4} \pm 4.3 \times 10^{3}$ \\
\hline
\end{tabular}

The most contaminated point with total psychrotrophic count was in cheese vat followed by water supply. The highest $S$ aureus count was found in cheese handler followed by the wall.

Table 3: Total enteroococci count and Total yeast and mold count during processing steps of white soft cheese in traditional dairy plant.

\begin{tabular}{ccc}
\hline Item & Enteroococci count & total yeast and mold count \\
\hline Incoming raw milk & $4.5 \times 10^{2} \pm 1.4 \times 10^{2}$ & $8.3 \times 10^{2} \pm 2.3 \times 10$ \\
\hline Cheese vat & $7.8 \times 10^{2} \pm 2.4 \times 10^{2}$ & $6.4 \times 10^{2} \pm 1.8 \times 10^{2}$ \\
\hline Cheese mould & $6.4 \times 10^{2} \pm 2.8 \times 10^{2}$ & $5.8 \times 10^{3} \pm 1.3 \times 10^{2}$ \\
\hline Wooden table & $2.8 \times 10^{4} \pm 1.3 \times 10^{2}$ & $3.4 \times 10^{3} \pm 1.6 \times 10^{2}$ \\
\hline Cheese handler & $7.2 \times 10^{2} \pm 2.5 \times 10^{3}$ & $6.8 \times 10^{2} \pm 2.3 \times 10^{2}$ \\
\hline Water supply & $1.3 \times 10^{3} \pm 4.7 \times 10^{2}$ & $5.9 \times 10^{2} \pm 1.7 \times 10^{2}$ \\
\hline Wall & $7.3 \times 10^{2} \pm 3.2 \times 10^{2}$ & $6.6 \times 10^{2} \pm 1.9 \times 10^{2}$ \\
\hline Plastic package & $4.5 \times 10^{2} \pm 1.1 \times 10^{2}$ & $8.9 \times 10^{2} \pm 2.6 \times 10^{2}$ \\
\hline Soft cheese & $7.5 \times 10^{4} \pm 2.4 \times 10^{3}$ & $6.3 \times 10^{4} \pm 4.2 \times 10^{3}$ \\
\hline
\end{tabular}

The most contaminated point with Enterococci was wooden table followed by water supply the most contaminated point with yeast and mold was cheese mould followed by wooden table. 


\section{DISCUSSION}

Most of the locally manufactured dairy products are liable to be contaminated with different types of microorganisms from different sources including steps of manufacture. For the production of dairy products of high microbiological quality, all surfaces of dairy equipment must be properly cleaned and sterilized. It is better and advisable to apply sanitation system, in the dairy plants and factories, for all surfaces on which milk comes in contact during manufacturing.

The microbial quality and safety of Egyptian white soft cheese, is the major area of concern for producers, public health authorities and consumers. It depends on the types of microorganisms introduced from raw milk, efficiency of processing and the hygienic practice applied in small or big dairy plant or informal producers. Handling of milks during cheese manufacture play an important role in the proliferation of microbial flora and consequently impair its utility and render the product unfit for human consumption, raw milk should be purchased from inspected and approved suppliers and should be stored and distributed under conditions that prevent microbial growth and contamination (EL-Baradei et al., (2007).

The data in Table 1 revealed that the mean total mesophilic bacterial count during processing steps of white soft cheese were $3.2 \times 10^{5} \pm 1.3 \times 10^{4}, 4.6 \times 10^{5}$ $\pm 1.9 \times 10^{4}, 9.4 \times 10^{6} \pm 3.7 \times 10^{4}, 8.5 \times 10^{5} \pm 4.6 \times 10^{3}$ and $7.5 \times 10^{5} \pm 6 \times 10^{4}$ for incoming raw milk, Cheese vat, Cheese mould, Wooden table and Cheese handler respectively. While the total mesophilic bacterial counts for Water supply, Wall, Plastic package and Soft cheese were $9.4 \times 10^{5} \pm 1.7 \times 10^{3}, 5.8 \times 10^{5} \pm$ $4.8 \times 10^{4}, 2.1 \times 10^{6} \pm 3.6 \times 10^{4}$ and $3.9 \times 10^{7} \pm 2.8 \times 10^{5}$ ,respectively. The highest total mesophilic bacterial count was found in Cheese mould by $9.4 \times 10^{6} \pm$ $3.7 \times 10^{4} \mathrm{cfu} / \mathrm{cm}^{2}$ followed by Plastic package with $2.1 \times 10^{6} \pm 3.6 \times 10^{4} \mathrm{cfu} / \mathrm{cm}^{2}$. These results similar to that obtained by (Abdou, 1990). Total counts of bacteria are the most useful indicator for the microbiological status of the cheese. A high viable count often Indicates contamination of raw material, unsatisfactory sanitation, or unsuitable time and temperature during storage and/or Production. (Mossel, 1983). The presence of high total mesophilic bacterial count in raw milk indicates serious faults in production and handling or may be due to lack of cooling facilities during transportation (Mehari and Gashe, 1990).

Also, Table 1 showed that The total coliforms count during processing steps of white soft cheese were $4.2 \times 10^{3} \pm 7.2 \times 10^{2}, 6.1 \times 10^{4} \pm 1.11 \times 10^{3}, 2.1 \times 10^{2} \pm$ $0.28 \times 10,6.2 \times 10^{2} \pm 3.5 \times 10$ and $5.6 \times 10^{3} \pm 1.8 \times 10^{2}$ for incoming raw milk, cheese vat, cheese mould, wooden table and cheese handler, respectively.
While, the total coliforms count for Water supply, Wall, Plastic package and Soft cheese were $3.9 \times 10^{2} \pm$ $1.6 \times 10^{2}, 5.7 \times 10^{2} \pm 4.3 \times 10^{2}, 3.8 \times 10^{2} \pm 1.4 \times 10^{2}$ and $2.4 \times 10^{2} \pm 1.3 \times 10$ respectively.

The most contaminated point with coliforms was cheese vat with a mean count of $6.1 \times 10^{4} \pm 1.11 \times 10^{3}$ followed by cheese handler with mean count of $5.6 \times 10^{3} \pm 1.8 \times 10^{2}$. In recent years attention paid toward coliform bacteria because of their public health importance, faecal coliforms are widely distributed in nature. They gain entry to milk and milk products through the water supply, equipment, unhygienic conditions of production and handling (Hafez, 1984).

All examined white soft cheese samples not complied with Egyptian standards (2005) which stated that coliform count should not be more than $10 \mathrm{cfu} / \mathrm{g}$.

The results in Table 2 showed that the total psychrotrophic count during processing steps of white soft cheese were $3.2 \times 10^{4} \pm 1.7 \times 10^{3}, 4.5 \times 10^{5} \pm$ $6.4 \times 10^{4}, 7.4 \times 10^{4} \pm 2.7 \times 10^{4}, 6.8 \times 10^{4} \pm 2.3 \times 10^{4}$ and $5.8 \times 10^{4} \pm 3.6 \times 10^{4}$ for incoming raw milk, cheese vat, cheese mould, wooden table and cheese handler, respectively. Mean while total psychrotrophic count for water supply, wall, plastic package and soft cheese were $3.7 \times 10^{5} \pm 1.9 \times 10^{4}, 8.7 \times 10^{4} \pm 3.4 \times 10^{4}$, $6.8 \times 10^{4} \pm 8.5 \times 10^{4}$ and $5.9 \times 10^{7} \pm 6.3 \times 10^{6}$ respectively.

The most contaminated point with total psychrotrophic count was cheese vat with a mean count of $4.5 \times 10^{5} \pm 6.4 \times 10^{4}$ followed by water supply with a mean count of $3.7 \times 10^{5} \pm 1.9 \times 10^{4}$. Psychrotrophs in general found in water and soil and introduced in milk and milk products through these sources and established on milk contact surfaces and drain in the processing plants. Psychrotrophic bacteria are responsible for many undesirable changes in flavor and body texture of dairy products. (APHA, 1992). Psychrotrophs produce extracellular thermostable proteolytic and lipolytic enzymes which responsible for off flavor and yield loss in cheese manufacture (Prieto et al., 2002).

Table 2 revealed that the $S$. aureus counts during processing steps of white soft cheese were $5.6 \times 10^{3} \pm$ $6.9 \times 10^{2}, 2.5 \times 10^{3} \pm 1.5 \times 10^{3}, 2.4 \times 10^{3} \pm 1.7 \times 10^{3}, 1.8 \times 10^{3}$ $\pm 3.7 \times 10^{3}$ and $9.4 \times 10^{4} \pm 5.6 \times 10^{3}$ for incoming raw milk, cheese vat, cheese mould, wooden table and cheese handler, respectively. Also we found that the $S$. aureus counts during processing steps of soft cheese were $6.5 \times 10^{2} \pm 1.7 \times 10^{2}, 8.5 \times 10^{3} \pm 2.3 \times 10^{3}$, $3.6 \times 10^{3} \pm 1.6 \times 10^{3}$ and $7.8 \times 10^{4} \pm 4.3 \times 10^{3}$ for water supply, wall, plastic package and soft cheese, respectively.

The highest $S$ aureus count was found in cheese handler by $9.4 \times 10^{4} \pm 5.6 \times 10^{3}$ followed by the wall with a mean count of $8.5 \times 10^{3} \pm 2.3 \times 10^{3}$. 
The presence of large number of $S$. aureus in dairy products is considered a good indicator of personal hygiene of factory workers with respiratory infections and suppurative lesions as boils (Kamat et al., 1991). S. aureus can gain access to milk either by direct excretion from udders with clinical or subclinical staphylococcal mastitis or by contamination from the environment during handling and processing of raw milk (Peles et al., 2007). Staphylococcus aureus may be the main cause of several food intoxication outbreaks for their production of heat stable enterotoxins (ICMSF, 1996). All examined white soft cheese samples not complied with the Egyptian standards (2005) which stated that white soft cheese should be free from any pathogenic organisms.

Table 3 showed that the Enterococci counts during processing steps of white soft cheese were $4.5 \times 10^{2} \pm$ $1.4 \times 10^{2}, 7.8 \times 10^{2} \pm 2.4 \times 10^{2}, 6.4 \times 10^{2} \pm 2.8 \times 10^{2}$, $2.8 \times 10^{4} \pm 1.3 \times 10^{3}$ and $7.2 \times 10^{2} \pm 2.5 \times 10^{2}$ For incoming raw milk, cheese vat, cheese mould, wooden table and cheese handler, respectively. Also we found that the Enterococci counts were $1.3 \times 10^{3} \pm$ $4.7 \times 10^{2}, 7.3 \times 10^{2} \pm 3.2 \times 10^{2}, 4.5 \times 10^{2} \pm 1.1 \times 10^{2}$ and $7.5 \times 10^{4} \pm 2.4 \times 10^{3}$. For water supply, wall, plastic package and soft cheese, respectively. The most contaminated point with Enterococci was wooden table with a mean value of $2.8 \times 10^{4} \pm 1.3 \times 10^{2}$ followed by water supply with a mean count of $1.3 \times 10^{3} \pm 4.7 \times 10^{2}$. Enterococci are widely distributed in nature, they gain entry into milk and milk products through the water supply, equipment and unhygienic conditions of production and handling. They have been incriminated as direct or indirect cause of food born infection and food poisoning outbreaks (Garg and Mital, 1991).

The high count of Enterococci may be due to inadequate heat treatment and bad conditions of production and unsanitary handling of the product, their presence in dairy products was unaccepted as the most passive indicator of fecal contamination.

It is evident from Table 3 that the total yeast and mold count during processing steps of white soft cheese were $8.3 \times 10^{2} \pm 2.3 \times 10,6.4 \times 10^{2} \pm 1.8 \times 10^{2}$, $5.8 \times 10^{3} \pm 1.3 \times 10^{2}, 3.4 \times 10^{3} \pm 1.6 \times 10^{2}$ and $6.8 \times 10^{2}$ $\pm 2.3 \times 10^{2}$, respectively.

While, for water supply, wall, plastic package and soft cheese were $5.9 \times 10^{2} \pm 1.7 \times 10^{2}, 6.6 \times 10^{2} \pm 1.9 \times$ $10^{2}, 8.9 \times 10^{2} \pm 2.6 \times 10^{2}$ and $6.3 \times 10^{4} \pm 4.2 \times 10^{3}$ respectively. The most contaminated point with yeast and mould was cheese mould with a mean count of $5.8 \times 10^{3} \pm 1.3 \times 10^{2}$ followed by wooden table with a mean count of $3.4 \times 10^{3} \pm 1.6 \times 10^{2}$. The cheese is considered as an excellent medium for yeast and molds that may induce undesirable changes such as colour defects, off -flavour and actual rots (Mislivec et al., 1992).
The public health significance of yeasts and moulds has been emphasized as certain types of moulds produce mycotoxins which were implicated in human cases of food poisoning and liver cancer. All examined white soft cheese samples not complied with Egyptian standards (2005) which stated that total yeast counts must be less than $400 \mathrm{cfu} / \mathrm{g}$ and total mold counts must be less than $10 \mathrm{cfu} / \mathrm{g}$.

The microbiological quality of the milk and the good manufacturing practices will contribute to the safety of the final product, especially in cheeses where milk is not pasteurized (FDA, 2001).

All food manufactures have a responsibility to have a full knowledge of the risks involved in their process, extending from raw materials through to consumption. The hazard analysis and critical control point (HACCP) system is described as a preventive tool for dairy manufacture (Woodhall, 1989).

\section{RECOMMENDATIONS and CONCLUSION}

Soft cheeses might represent a health risk for the consumers and considered as a possible vehicle of infection or vehicle of transmission for wellestablished pathogens so the cheese made in street, farmers' home or in unlicensed factories is not safe for human consumption. More and more of proper inspection must be done on street markets, supermarkets, stores, plants, unlicensed factories of dairy products. The development and application of microbiological hazard must follow established basic principles to control presence or growth of microorganisms.

To improve the safety of these product efforts to raise awareness of the importance of hygiene barriers and raw milk quality as well as improved process control can be suggested, we can recommend that the receiving of raw milk should be carefully monitored and only obtained from suppliers apply good manufacturing practices. Also strict hygienic measures of cleaning and sanitization of all food contact surfaces and hygienic training of plant workers should be applied to avoid contamination, water supply must be clean and comply with the standard requirements, preventation of environmental contamination, good cleaning and sanitizing of food processing is essential to produce safe and high quality cheese. Good conditions of hygiene should be maintained throughout cheese manufacture until consumption to prevent contamination. HACCP based risk assessment, good manufacturing practice and ISO 22000 food safety should be implemented for all stages of manufacture in order to produce safe and good quality dairy product. 


\section{REFERENCES}

American Public Health Association, A.P.H.A.(1992): Standard Methods for the Examination of Dairy Products. $16^{\text {th }}$ Ed., American Public Health Association, Washington, D.C.

Abdou, A.M. (1990): Dairy utensils as a source of contamination of raw milk in dairy farms. M.V. SC., Fac. Vet. Med. Moshtohor, Zagazig Univ.

Abou Dawood, A.I.; Soada, H. and Taha, Mohamed, M.A. (2005): Chemical and microbiological quality of raw milk, soft and hard cheeses collected from districts at Giza governorate. Egyptian J. Dairy Sci., 33:201-214.

Aly, S.A. and Galal, E.A. (2002): Effect of Milk Pretreatment on the Keeping Quality of Domiati Cheese. Pakistan Journal of Nutrition1 (3): 132-136.

Bailey, W.R. and Scott, E.G. (1998): Diagnostic Microbiology. A Text book for Isolation and Identification of Pathogenic Microorganism's. The C.V. Mosby Company Saint Louis.

Banwart, G.J. (1998): Basic Food Microbiology. $2^{\text {nd }}$ Ed. CBS Publishers and Distributors. New Delhi 11002. (India).

Besancon, X.; Smet, C.; Chabalier, C.; Rivemale, M.; Reverbel, J.P.; Ratomahenina, R. and Galzy, $P$. (1992): Study of surface flora of cheese. International Journal of Food Microbiology, 17:9-18.

Centers for Disease Control and Prevention (CDC, 2009): Surveillance for food borne disease outbreak, United States, 2006. Morbidity Mortality Weekly Rep., 58: 609-615.

Efthymiou, C.J.; Baccash, P.; Labombardi, V.J. and Eostein, D.S. (1974): Improved isolation and identification enterococci in cheese. Appl. Microbial. 28, 3.417-422.

Egyptian standard (2005): general standard for soft cheese, ES:1008-3.

El-Baradei, G.; Delacroix-Buchet, A. and Ogier, J. (2007): Biodiversity of Bacterial Ecosystems in Traditional Egyptian Domiati Cheese. Appl. and Enviro. Microbio. Vol. 73, No. 4 p. 12481255.

FDA, Food and Drug Administration (2002): Bacteriological Analytical Manual. $9^{\text {th }}$ Ed., AOAC International, Arlington, VA, USA.

Garg, S.K. and Mital, B.K. (1991): Enterococci in milk and milk products. Critical Reviews in Microbiology, 18(1):15-45. Department of microbiology G.P. pant Univ. Agric. And Tech. Pantangar, 263:145, Nainital, U.P., India.

Hafez, N.M. (1984): incidence and public health importance of coliform with special references to enteropathogenic serotype of E. coli in milk and some dairy products."M.v.Sc. Thesis, Fac. Vet. Med., Cairo Univ.

Hamed, A. (1992): Effect of pasteurization and storage conditions on the microbiological, chemical and organoleptic properties of Domiatia cheese during pickling. Egypt. J.Dairy Sci., Vol.20:177-190.

Hayes, M.C.; Ralyea, R.D.; Murphy, S.C.; Carey, N.R.; Scarlett, J.M. and Boor, K.J. (2001): Identification and characterization of elevated microbial counts in bulk tank raw milk. J. Dairy Sci. 84, 292-298.

ICMSF, (1996): "International Committee on Microbiological Specification of Food, Microorganism in foods. Microbiological specification of food pathogens, 1 st Ed. Black academic and professional, London, Pages 112-300.

ISO (1991): General guidance for enumeration of Coliform ISO 1991-8432.

ISO (4833/2003): Microbiology of food and animal feeding stuff. Horizontal method for the Enumeration of microorganisms- colony count technique at $30 \mathrm{c}^{\circ}$.

Kamat, M.Y.; Sulebele, G. and Nairupama, Sabnis (1991): A comparative evaluation of media for enumeration of enterotoxigenic staphylococci by selective enrichment technique. J. Food Sci. Technol., India, 28(6):381-383.

Kassem, M.; Salem, E.; Ahwal, A.M.; Saddik, M. and Gomaa, N.F (2002): Application of hazard analysis and critical control point system in the dairy Industry Eastern Mediterranean Health Journal Volume 8, no. I.

Mehari, T. and Gashe B.A. (1990): A survey of the microflora of raw and pasteurized milk and the sources of contamination in milk processing plant in Addis Ababa, Ethiopia, J. Dairy Res. Vol. 57:233-238.

Mislivec, P.B.; Beuchat, L.R. and Cousin, M.A. (1992): Yeasts and molds. Chapter 16 Compendium of Methods for Microbiological Examination of Fod. $3^{\text {rd }}$ Ed., American Public Health Association. Washington, DC.

Mossel, D.A.A. (1983): Essential and preservatives of the microbial ecology of foods. In: Roberts TA, Skinner FA, editors. Food microbiology: advances and prospects. London: Academic Press.

Pelecszynska, E. and Libelt, K. (1995): Analysis of hygienic risk factors and critical control points in milking and processing of raw milk for consumption. Medycyna-Weterynaryjna, 51(7): 396-399; 42 Dublin Poland.

Peles, F.; Wagner, M.; Varga, L.; Hein, I.; Rieck, P.; Gutser, K.; Kereszturi, P.; Kardos, G.; Turcsanyi, I.; Beri, B. and Szabo, A. (2007): Characterization of Staphylococcus aureus strains isolated from bovine milk in Hungary. 
International Journal of Food Microbiology.; 118: 186-193.

Pritchard, T.J.; Beliveau, C.M.; Flanders, K.J. and Donnelly, C.W. (1994): Increased incidence of listeria species in dairy processing plants having adjacent farm facilities. J. Food Prot., 57(9):770-775.

Prieto, B.; Franco, I. and Bernardo, A. (2002): Proteolytic and lipolytic changes during the ripening of Leon raw cow, s milk cheese, a Spanish traditional variety. Int. J. food Sci.Technol. 37: 661-671.

Silliker, J.H. (1987): Principles and applications of the HACCP approach for the food processing industry. In food protection technology, Ed. C.W. Felix, chelsen, USA, Lewis Publishers Inc.
UNEP. (1992): "The contamination of foods, UNEP/GEMS environmental library. No. 5. UNEP, Nairobi.

Woodhall, Mrtin (1989): the application of hazard analysis and critical control point system to milk powder manufacture. Journal of the society of Dairy Technology, Vol. 42, Nov., 1989.

Yousef, H.M. and Sobieh, Nagedan, K. (2001): Microbial status of Domiati cheese at $\mathrm{Al}$ Gassiem area Saudi Arabia. 8th Sci. Con. Fac. Vet. Med. Assiut University, p: 91-97.

Sadek, I. Zeinab; Hosny, I.M.; El Kholy, W.I. and El Dairouty, R.K. (2009): Comparative investigations for detection of food borne microorganisms in Egyptian cheese using conventional and fast biochemical tests. Global Veterinaria (3): 189-195.

\section{تقييم المخاطر الميكروبية أثناء إنتاج الجبن الأبيض في احد مصانع الألبان التقليدية أحمد صلاح اللدين عياد}

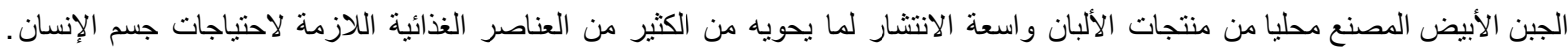

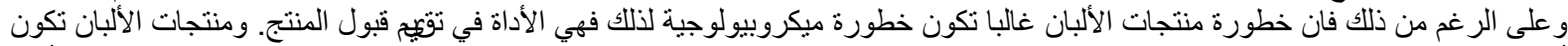

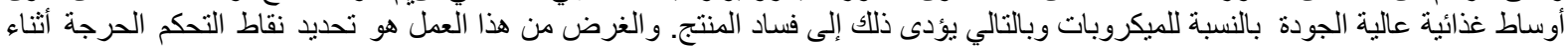

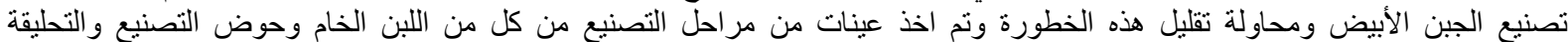

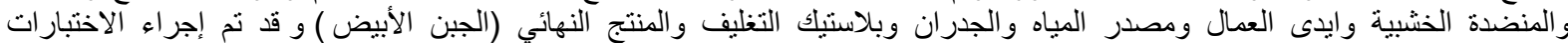

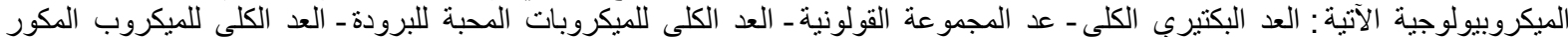

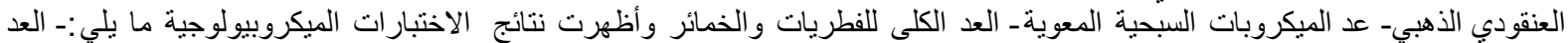

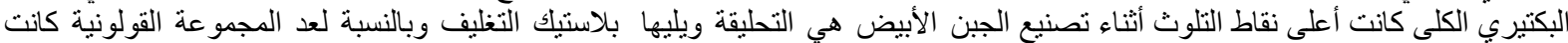

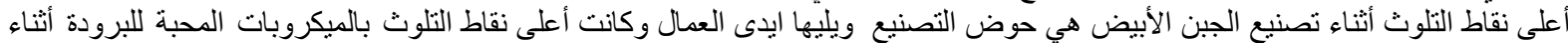

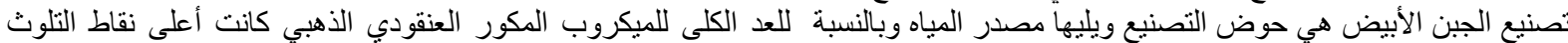

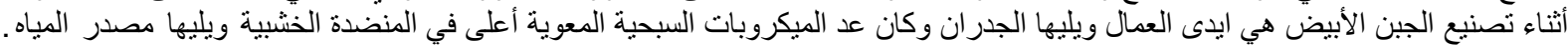

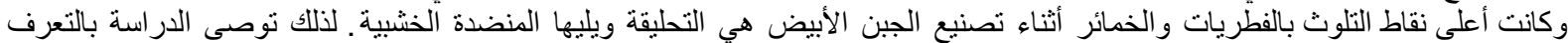

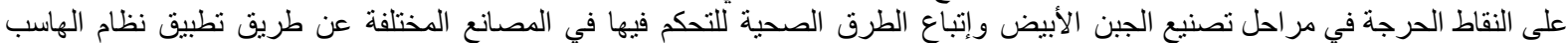

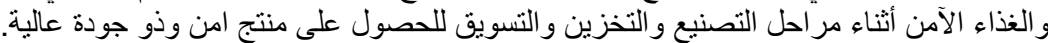

